\title{
UPAYA HUKUM PENYELESAIAN SENGKETA JUAL BELI TANAH SECARA DI BAWAH TANGAN
}

\author{
Abdul Wahid, Elya Kusuma Dewi, Sarip \\ Fakultas Hukum, Universitas Muhammadiyah Cirebon \\ Jalan Tuparev Nomor 70 Cirebon, Jawa Barat 45153, Indonesia \\ E-mail:abdul.wahid@umc.ac.id, elyakusumadewi@gmail.com, sarip_anisa@yahoo.co.id
}

\begin{abstract}
Abstrak
Tanah dan bangunan adalah benda tidak bergerak (benda tetap) sehingga proses jual belinya berbeda dengan jual beli benda bergerak seperti kendaraan, televisi, dan lain-lain. Secara hukum, jual beli benda bergerak terjadi secara tunai dan seketika, yaitu selesai ketika pembeli membayar harganya dan penjual menyerahkan barangnya. Hal tersebut berbeda dengan jual beli tanah dan bangunan yang memerlukan akta otentik. Penelitian ini mengkaji tindakan hukum masyarakat awam yang menjadi polemik terkait jual beli tanah secara di bawah tangan. Penulis melakukan penelitian hukum normatif (normative law research) menggunakan studi kasus normatif berupa produk perilaku hukum. Teknik analisis yang digunakan adalah inventarisasi hukum positif, asas-asas dan doktrin hukum, penemuan hukum dalam perkara in concreto, sistematik hukum, taraf sinkronisasi, perbandingan hukum dan sejarah hukum. Kajian ini menyimpulkan bahwa praktik jual beli tanah secara di bawah tangan adalah sah dan mengikat secara hukum serta pembeli juga dapat untuk memproses peralihan hak/balik nama Sertifikat Hak Milik (SHM) dari penjual kepada pembeli.
\end{abstract}

Kata Kunci : Sengketa, Jual Beli Tanah, Di Bawah Tangan.

\begin{abstract}
Land and buildings are immovable objects (fixed objects) so the buying and selling process is different from buying and selling movable objects such as vehicles, televisions, and others. Legally, the sale and purchase of movable objects occur in cash and instantaneously, that is, completed when the buyer pays the price and the seller surrenders the goods. This is different from buying and selling land and buildings that require authentic deeds. This study examines the legal actions of ordinary people who become polemic related to buying and selling land under the hand. The author conducts normative law research using normative case studies in the form of legal behavior products. The analysis technique used is an inventory of positive law, principles, the doctrine of law, legal discovery in concreto cases, systematic law, synchronization level, comparative law, legal history. This study concludes that the practice of buying and selling under the hand is legal and legally binding and the buyer is also able to process the transfer of title of ownership certificate (SHM) from the seller to the buyer.
\end{abstract}

Keywords: Dispute, Buying and Selling Land, Under the hand. 


\section{A. PENDAHULUAN}

Manusia adalah makhluk sosial (zoon politicon) dimana mereka saling membutuhkan satu sama lain. Dengan adanya hubungan timbal balik, maka sering kali timbul fenomena sosial berupa konflik yang timbul akibat adanya kepentingan yang berbeda-beda. Dengan timbulnya konflik, maka hukum memegang peranan penting dalam menyelesaikan konflik tersebut. ${ }^{1}$

Tanah merupakan kebutuhan pokok yang sangat dibutuhkan bagi kehidupan seluruh manusia, karena tanah merupakan salah satu unsur utama bagi kelangsungan hidup dan kehidupan manusia sepanjang masa, dengan tujuannya adalah dipergunakan untuk tercapainya kemakmuran bagi seluruh rakyat yang terbagi secara merata baik secara materil maupun spritual. Meningkatnya kebutuhan akan tanah karena jumlah penduduk yang semakin bertambah, sehinggah wajar bila manusia selalu berusaha untuk mendapatkan dan memperoleh tanah diantaranya melakukan dengan cara jual beli tanah. Namun terkadang penguasaan dan perolehan tanah menimbulkan masalah hukum atau bahkan pertentangan atau perselisihan baik dikalangan keluarga sendiri atau terhadap orang lain bahkan dipemerintahan dalam penguasaan atau kepemilikan atas tanah. ${ }^{2}$

Tanah sangat erat hubungannya dengan kehidupan manusia sehari hari, bahkan dapat dikatakan setiap saat manusia berhubungan dengan tanah. Setiap orang memerlukan tanah tidak hanya pada masa hidupnya, tetapi sudah

1 Nurnaningsih Amriani, "Mediasi Alternatif Penyelesaian Sengketa Perdata Di Pengadilan" (Jakarta: PT Rajagrafindo Persada, 2011), 1.

${ }^{2}$ Cici Fajar Novita, "Tinjauan Hukum Terhadap Jual Beli Tanah Tanpa Akta Ppat (Wilayah Kecamatan Tinombo)," Jurnal Ilmu Hukum Legal Opinion 2, no. 5 (2014), http://jurnal.untad.ac.id/jurnal/index.php/LO/article/vie w/5773/4536. meninggalpun masih tetap berhubungan dengan tanah. ${ }^{3}$

Dalam masyarakat perolehan tanah lebih sering dilakukan dengan pemindahan hak, yaitu dengan melalui jual beli. Perkataan jual beli dalam pengertian sehari-hari dapat diartikan, di mana seseorang melepaskan uang untuk mendapatkan barang yang dikehendaki secara sukarela. Kemudian menurut Hukum Perdata (BW) Pasal 1457 disebutkan bahwa jual-beli tanah adalah suatu perjanjian dengan mana penjual mengikatkan dirinya (artinya berjanji) untuk menyerahkan tanah yang bersangkutan kepada pembeli yang mengikatkan dirinya untuk membayar kepada penjual harga yang telah disepakatinya. ${ }^{4}$

Istilah jual beli hak atas tanah hanya disebutkan dalam Pasal 26 UUPA yaitu yang menyangkut jual beli hak milik atas tanah. Ketentuan yang terdapat dalam pasal-pasal lainnya tidak ada kata yang menyebutkan jual beli, tetapi disebutkan sebagai dialihkan. Pengertian dialihkan menunjukkan suatu perbuatan hukum yang disengaja untuk memindahkan hak atas tanah kepada pihak lain melalui jual beli, hibah, tukar menukar dan hibah wasiat. Jadi, meskipun dalam pasal hanya disebutkan dialihkan, termasuk salah satunya adalah perbuatan hukum pemindahan hak atas tanah karena jual beli. ${ }^{5}$ Mengingat pentingnya kepastian hukum dalam setiap peralihan tanah sebagai akibat dari transaksi jual beli hak atas tanah maka oleh UUPA diwajibkan untuk melakukan pendaftaran peralihan hak karena jual beli tersebut.

\footnotetext{
${ }^{3}$ K. Wantjik Saleh, Hak Anda Atas Tanah (Jakarta: Ghalia Indonesia, 1982), 7.

${ }^{4}$ Prancisca Romana et al., "Keabsahan Jual Beli Hak Atas Tanah Dibawah Tangan Di Desa Patihan Kecamatan Sidoharjo Kabupaten Sragen (Tinjauan Beberapa Kasus Terkait Di Pengadilan Negeri Di Surakarta )," Jurnal Repertorium II, No. 2 (2015): 117125.

${ }^{5}$ Adrian Sutedi, Peralihan Hak Atas Tanah Dan Pendaftaranya, (Jakarta: Sinar Grafika, 2006), 11.
} 
Perbuatan hukum yang dilakukan tertulis jauh lebih baik karena lebih aman dan terjamin kepastian hukumnya apabila dituangkan secara tertulis. Meningkatnya tuntutan masyarakat akan kepastian hukum mendorong kebutuhan akan pelayanan dari pejabat umum dalam bidang pembuatan alat bukti guna menjamin kepastian hukum tersebut. Dalam hal adanya hubungan hukum itu, seringkali timbul suatu keadaan dimana pihak yang satu tidak memenuhi kewajibannya terhadap pihak lainnya sehingga salah satu pihak merasa dirugikan haknya, untuk mempertahankan hak dan memenuhi kewajiban seperti yang telah diatur dalam hukum, dalam penyelesaiannya harus berdasarkan pada peraturan hukum yang telah ditetapkan dan diatur dalam undang-undang. Demi menjamin kepastian hukum, khususnya berkaitan dengan kekuatan pembuktian atas perbuatan hukum tersebut, selain dapat dilakukan secara lisan maka juga dapat dilakukan secara tertulis. ${ }^{6}$

Praktiknya di masyarakat dalam transaksi jual beli hak atas tanah masih banyak dilakukan dibawah tangan yaitu jual beli hak atas tanah antara penjual dan pembeli yang dilakukan di hadapan kepala desa yang bersifat tunai, nyata dan terang. Tunai dan nyata artinya bahwa pada saat pembeli membayar harga tanah kepada penjual, maka pada saat itu tanah telah beralih dari penjual kepada pembeli atau dengan kata lain bahwa sejak saat itu pembeli telah mendapatkan hak milik atas tanah tersebut. Sedangkan terang artinya bahwa dengan dilakukannya jual beli dihadapan kepala desa sudah terjamin bahwa tidak terjadi pelanggaran hukum

\footnotetext{
${ }^{6}$ Abdul Wahid, Elya Kusuma Dewi, and Sarip Sarip, "Kekuatan Alat Bukti Akta Otentik Terhadap Akta Pejabat Pembuat Akta Tanah ( PPAT ) Berdasarkan Peraturan Pemerintah Nomor 24 Tahun 2016 Juncto Pasal 1868 KUHPerdata," Mahkamah: Jurnal Kajian Hukum Islam 4, No. 2 (2019): 205-19, https://doi.org/10.24235/mahkamah.v4i2.5372.
}

dalam jual beli tersebut atau jual beli itu dianggap terang sehingga masyarakat mengakui keabsahannya. Dengan bukti pembelian berupa selembar kwitansi ini dalam jangka waktu pendek masih belum mempunyai dampak hukum bagi pembeli, karena apabila pembeli ingin melakukan perbuatan hukum terhadap hak atas tanahnya masih bisa menghubungi pihak penjual, tetapi dalam jangka waktu panjang akan berpotensi menimbulkan sengketa di kemudian hari.

Berkenaan dengan fenomena tersebut di atas yang menjadi permasalahan yang akan diteliti adalah upaya hukum bagi pihak pembeli apabila dikemudian hari pihak penjual dan ahli warisnya mempersoalkan transaksi jual beli tanah yang dilakukan pihak pembeli tersebut yang telah nyata-nyata sudah membeli tanah dari pihak penjual, yang menurut peraturan perundang-undangan yang berlaku jual beli hak atas hanya dapat didaftarkan apabila akta peralihan hak karena jual beli tersebut dibuat oleh PPAT. Hal ini penting khususnya bagi penulis untuk mengetahui upaya hukum yang dilakukan bagi pembeli terhadap jual beli yang dilakukan secara di bawah tangan.

\section{B. PEMBAHASAN}

\section{Ketentuan Jual Beli Hak Atas Tanah}

Apabila peralihan hak atas tanah karena jual beli dilakukan dihadapan PPAT, maka akan mempunyai alat bukti yang kuat atas peralihan hak atas tanah yang bersangkutan, karena akta PPAT adalah merupakan akta otentik. Meskipun administrasi PPAT sifatnya tertutup, tetapi PPAT wajib menyampaikan akta yang bersangkutan kepada Kantor Pertanahan setempat untuk didaftar. Hal ini bertujuan agar diketahui oleh umum, sehingga setiap orang dianggap mengetahuinya. Setiap pembuatan akta di hadapan PPAT, harus disampaikan kepada Kantor Pertanahan dalam jangka waktu 7 (tujuh) hari sejak 
ditandatanganinya akta oleh PPAT yang bersangkutan untuk didaftar. ${ }^{7}$

Ketentuan hukum yang harus diterapkan adalah jual beli tanah yang harus sesuai dengan yang diatur di dalam Undang-Undang Nomor 5 Tahun 1960 tentang Undang-Undang Pokok Agaria dan Peraturan Pemerintah Nomor 10 Tahun 1961 yang di ganti dengan Undang-Undang Nomor 24 Tahun 1997 Tentang Pendaftaran tanah. Bahwa jual beli tanah seharusnya dilakukan dihadapan PPAT dengan dibuatkan suata akta jual beli tanah. Setelah proses jual beli dilakukan di hadapan PPAT, haruslah setelah itu dilakukan proses pendaftaran tanah berupa balik nama di Kantor Pertanahan melalui PPAT untuk mengganti nama yang terdapat pada sertipikat menjadi nama pemilik baru yang sebenarnya atas tanah tersebut. Dengan dilakukannya pendaftaran tanah tersebut, maka pemilik tanah yang sebenarnya akan mendapatkan sertipikat tanah dengan namanya tercantum di sertipikat tersebut sebagai bukti kepemilikan tanah. Proses pendaftaran tanah tersebut berlaku untuk tanah baik yang belum maupun yang sudah didaftarkan. ${ }^{8}$

Jual beli yang dilakukan tanpa akta jual beli PPAT dapat dikatakan bahwa statusnya telah mengikat antara pihak penjual dengan pembeli, akan tetapi perbuatan hukum tidak dapat didaftarkan di Kantor Pertanahan untuk melakukan perubahan data kepemilikan atas tanah dan bangunan tersebut. Dan untuk membuat jual beli tanah tersebut menjadi sah, maka segera datang ke PPAT untuk dibuatkan akta jual beli tanah. Alasanalasan mengapa orang melakukan jual beli

\footnotetext{
${ }^{7}$ Adrian Sutedi, Peralihan Hak Atas Tanah Dan Pendaftaranya, (Jakarta: Sinar Grafika, 2006), 80-81.

8 Marindi Cintyana, Keabsahan Jual Beli Di Bawah Tangan Atas Tanah Bersetipikat (Studi Kasus Perkara No 305/ Pdt G/ 2009/ PN Smg), Diponegoro Law Review, Volume 1, No. 4, Tahun 2012, 1-7. http://ejournal-s1.undip.ac.id/index.php/dlr.
}

hak atas tanah dilakukan secara di bawah tangan, antara lain:

1) Ketidaktahuan orang yang bersangkutan terhadap proses atau prosedur jual beli hak atas tanah;

2) Orang yang bersangkutan membayangkan bahwa urusan jual beli hak atas tanah itu sulit dan berbelit-belit,

3) Karena menghindari biaya-biaya yang tidak terduga yang mereka tidak ketahui;

4) Faktor ekonomi orang yang bersangkutan.

Teori ini akan digunakan untuk menganalisis dan menjawab pada permasalahan yaitu akibat-akibat hukum bagi pembeli terhadap jual beli hak atas tanah yang dilakukan secara bawah tangan.

Menurut Bachsan Mustafa Kepastian hukum ${ }^{9}$, adalah hukum administrasi negara positif harus dapat memberikan jaminan kepastian hukum kepada penduduk. Kepastian hukum mempunyai 3 (tiga) arti sebagai berikut $:^{10}$

a) Pasti mengenai peraturan hukumnya yang mengatur masalah pemerintah tertentu yang abstrak.

9 Kepastian hukum atau rechtssicherkeit, security, rechhtszekerheid, adalah suatu yang baru, yaitu sejak hukum itu dituliskan, dipositifkan dan menjadi publik. Kepastian hukum menyangkut masalah "law sicherkeit durch das recht" seperti memastikan bahwa pencurian, pembunuhan menurut hukum merupakan kejahatan. Kepastian hukum adalah kepastian tentang hukum itu sendiri. Terdapat tiga hal yang berhubungan dengan makna kepastian hukum, yaitu: a. Suatu hukum itu positif, artinya bahwa ia adalah perundang-undangan (gesetzliches Recht), b. Suatu hukum itu didasarkan pada fakta (Tatsachen), bukan suatu rumusan tentang penilaian yang nanti akan dilakukan oleh hakim, seperti "kemauan baik", "kesopanan", c. Suatu fakta itu harus dirumuskan dengan cara yang jelas sehingga menghindari kekeliruan dalam pemaknaan disamping juga mudah dijalankan, suatu hukum positif itu tidak boleh sering diubah-ubah". Lihat Achmad Ali, Menguak Teori Hukum dan Teori Peradilan, (Jakarta: Kencana Prenadamedia Group, 2009), 292-293.

${ }^{10}$ Bachsan Mustafa, Sistem Hukum Administrasi Negara Indonesia, (Bandung: Cipta Aditya Bakti, 2001), 53. 
b) Pasti mengenai kedudukan hukum dari subjek dan objek hukumnya dalam pelaksanaan peraturan-peraturan Hukum Administrasi Negara.

c) Mencegah kemungkinan timbulnya perbuatan sewenang-wenang (eigenrechting) dari pihak manapun, juga tidak dari pemerintah.

Berdasarkan uraian di atas sangat jelas apa yang sudah dikatakan bahwa kepastian hukum hanya berhubungan dengan keberadaan hukum perundangundangan. Memang benar di dalam suatu negara yang menganut sistem tertulis (civil law system, condification system), kepastian hukumnya dijamin dengan dituangkannya secara tertulis aturanaturan dan asas-asas hukum, namun demikian tidak berarti bahwa di dalam common law system yang didominasi oleh hukum tidak tertulis itu tidak memiliki alat untuk menjamin kepastian hukumnya. Pernyataan di dalam "common law system" kepastian hukum dijamin dengan berlakunya asas "stare decisis" atau "the binding force of presedent", yaitu kekuatan mengikat dari presedent di Indonesia dinamakan Yurisprudensi terhadap perkara-perkara sesudahnya yang sejenis.

Unsur dari keadilan adalah penghargaan dan penilaian, karena dalam keadilan menuntut suatu keadaan yang sama pada setiap manusia. Sesungguhnya keadilan itu berasal dari Tuhan tetapi seorang manusia diberi kemampuan untuk merasakan keadaan yang dinamakan adil itu. hukum itu tidak harus mencarikan keseimbangan antara berbagai unsur kepentingan yang menimbulkan konflik, untuk mendapatkan keadilan, dan untuk mendapatkan keseimbangan antara tuntutan keadilan dengan tuntutan dalam masyarakat.

\section{Upaya Hukum Penyelesaian Sengketa Jual Beli Tanah di Bawah Tangan}

\section{a. Mediasi (Non-Litigasi)}

Secara etimologi, istilah mediasi berasal dari bahasa latin, mediare yang berarti berada di tengah. Makna yang merujuk pada peran yang ditampilkan pihak ketiga sebagai mediator dalam menjalankan tugasnya menengahi dan menyelesaikan sengketa antara para pihak. Berada di tengah juga bermakna mediator harus berada pada posisi netral dan tidak memihak dalam menyelesaikan sengketa. Ia harus mampu menjaga kepentingan para pihak yang bersengketa secara adil dan sama, sehingga menumbuhkan kepercayaan (Trust) dari para pihak yang bersengketa. $^{11}$

Menurut Takdir Rahmadi mediasi adalah suatu proses penyelesaian sengketa antara dua pihak atau lebih melalui perundingan atau cara mufakat dengan bantuan pihak netral yang tidak memiliki kewenangan memutus. Pihak netral tersebut disebut dengan mediator dengan tugas memberikan bantuan procedural dan substansial. ${ }^{12}$ Pengertian mediasi menurut Jimmy Joses Sembiring bahwa mediasi adalah proses penyelesaian sengketa dengan pihak ketiga, yakni pihak yang memberikan masukan- masukan kepada para pihak untuk menyelesaikan sengketa. ${ }^{13}$

Pengertian mediasi menurut Perundang-undangan secara konkret dapat ditemukan dalam Pasal 1 ayat (1) Peraturan Mahkamah Agung Nomor 1 Tahun 2016 Tentang Prosedur Mediasi di Pengadilan, mediasi adalah cara penyelesaian sengketa melalui proses perundingan untuk memperoleh kesepakatan para pihak dengan dibantu oleh mediator. Mediator adalah hakim atau pihak lain yang memiliki sertifikat

${ }^{11}$ Mardalena Hanifah, "Kajian Yuridis Mediasi sebagai Alternatif Penyelesaian Sengketa Perdata di Pengadilan”, Jurnal HAPER, 2:1( Januari-Juni 2016), 3.

12 Takdir Rahmadi, Mediasi Penyelesaian Sengketa Melalui Pendekatan Mufakat, (Jakarta : PT Raja Grafindo Persada, 2012), 12-13.

13 Jimmy Joses Sembiring, Cara Menyelesaikan Sengketa di Luar Pengadilan, (Jakarta : Visimedia, 2011), 27. 
mediator sebagai pihak netral yang membantu para pihak dalam proses perundingan guna mencari berbagai kemungkinan penyelesaian sengketa tanpa menggunakan cara memutus atau memaksa sebuah penyelesaian. Hal ini termuat dalam Pasal 1 ayat (2) Peraturan Mahkamah Agung Nomor 1 Tahun 2008 tentang Prosedur Mediasi di Pengadilan. ${ }^{14}$

Dalam upaya perdamaian, tahap pertama yang harus dilakukan oleh hakim dalam menyidangkan perdamaian kepada pihak-pihak yang bersengketa adalah mengadakan perdamaian kepada pihakpihak yang bersengketa. Kemudian hakim dalam mendamaikan pihak-pihak yang berperkara adalah sejalan dengan ajaran agama Islam. Ajaran agama Islam memerintahkan agar menyelesaikan setiap perselisihan yang terjadi antara manusia sebaiknya dengan jalan perdamaian (islah). Ketentuan ini adalah sejalan dengan firman Allah SWT dalam AlQuran Surah Al-Hujarat ayat (9) yang berbunyi:

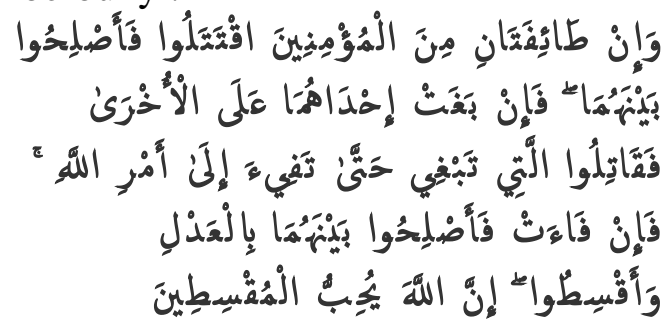

Artinya: "Dan kalau ada dua golongan dari mereka yang beriman itu berperang hendaklah kamu damaikan antara keduanya! Tapi kalau yang satu melanggar perjanjian terhadap yang lain, hendaklah yang melanggar perjanjian itu kamu perangi sampai surut kembali pada perintah Allah. Kalau dia telah surut, damaikanlah antara keduanya menurut keadilan, dan hendaklah kamu berlaku adil; sesungguhnya Allah mencintai orang-orang yang berlaku adil". 15

Yakni bahwa jika dua golongan orang beriman bertengkar maka

14 Peraturan Mahkamah Agung Nomor 1 Tahun 2016 Tentang Prosedur Mediasi di Pengadilan.

${ }^{15}$ https://tafsirq.com/49-al-hujurat/ayat-9. damaikanlah mereka, perdamaian itu hendaknya dilakukan secara adil dan benar sebab Allah sangat mencintai orang yang berlaku adil. ${ }^{16}$

Keputusan Badan Pertanahan Republik Indonesia Nomor 11 Tahun 2009 tentang kebijakan dan Strategi Kepala BPN Republik Indonesia Menangani dan Menyelesaiakan Sengketa, Konflik dan Perkara Pertanahan Tahun 2009, Keputusan Kepala Badan Pertanahan Nasional Nomor 34 Tahun 2007 tentang petunjuk Teknis Penanganan dan penyelesaian Masalah Pertanahan.

Salah satu metode penyelesaian kasus pertanahan ditetapkan melalui Mediasi dimana mekanisme pelaksaan Mediasi diatur di dalam Petunjuk Teknis Badan Pertanahan Nasional Republik Indonesia Nomor: 05/JUKNIS/D.V/2007, Keputusan Kepala BPN Republik Indonesia Nomor 34 Tahun 2007 tentang Mekanisme Pelaksanaan Mediasi.

Dasar hukum kewenangan Badan Pertanahan Nasional/ Kementerian Agraria dan Tata Ruang telah tercantum dalam Peraturan Menteri Agraria dan Tata Ruang/Kepala Badan Pertanahan Nasional Republik Indonesia Nomor 11 Tahun 2016 tentang Penyelesaian Kasus Pertanahan. Penyelesaian sengketa dan konflik dilakukan berdasarkan inisiatif dari Kementerian dan pengaduan masyarakat. Dalam menyelesaikan kasus pertanahan Penanganan Masalah dan Pengendalian Pertanahan menerangkan bahwa maksud penyelesaian kasus pertanahan sebagai berikut:

1) mengetahui riwayat dan akar permasalahan Sengketa, Konflik atau Perkara;

2) merumuskan kebijakan strategis penyelesaian Sengketa, Konflik atau Perkara; dan

3) menyelesaikan Sengketa, Konflik atau Perkara, agar tanah dapat

16 Abdul Manan, Penerapan Hukum Acara Perdata di Lingkungan Peradilan Agama, (Jakarta: Kencana Prenada Media, 2005), 151. 
dikuasai, dimiliki, dipergunakan dan dimanfaatkan oleh pemiliknya.

Penyelesaian Kasus Pertanahan bertujuan untuk memberikan kepastian hukum dan keadilan mengenai penguasaan, pemilikan, penggunaan dan pemanfaatan tanah. Penangan masalah pertanahan melalui lembaga mediasi oleh BPN biasanya didasarkan dua prinsip utama, yaitu:

1) Kebenaran-kebenaran formal dari fakta-fakta yang mendasari permasalahan yang bersangkutan;

2) Keinginan yang bebas dari para pihak yang bersengketa terhadap objek yang disengketakan.

Mediasi adalah bentuk dari pada proses perdamaian antara para pihak yang bersengketa dengan menyerahkan permasalahanya kepada mediator untuk diberikan solusi dan hasil akhir yang adil, biaya yang murah, dan dapat diterima oleh kedua belah pihak yang bersengketa secara sukarela. Mediasi dapat dibagi menjadi dua kategori, yaitu:

1) Mediasi Hukum

Mediasi secara hukum merupakan bagian dari litigasi, yakni hakim meminta kedua belah pihak untuk mengusahakan menyelesaikan sengketa pertanahan mereka diselesaikan melaui proses mediasi sebelum litigasi dilanjutkan.

2) Mediasi Pribadi.

Mediasi pribadi adalah penyelesaian sengketa yang ditentukan oleh pihak yang bersengketa dengan menunjuk seorang mediator sebagai pihak penengah / pihak netral. Tujuan dari pada mediator tersebut adalah menengahi para pihak yang bersengketa untuk mencapai suatu kesepakatan bersama secara damai dan tidak merugikan salah satu pihak yang bersengketa.

Tahapan atau proses mediasi diluar pengadilan atau non litigasi diatur dalam peraturan perundang-undangan pengaturanya hanya terbatas pada penggunaan mediasi. Aturan hukum yang menjadi dasar adalah Undang-Undang Nomor 30 Tahun 1999 Tentang Arbitrase Dan Alternatif Penyelesaian Sengketa. ${ }^{17}$ Undang-undang ini mengatur penggunaan arbitrase maupun alternatif penyelesaian sengketa yang sifatnya sukarela, maka mediasi yang digunakan dalam sengketa pertanahanpun bersifat sukarela. Ketentuan pada Pasal 23c PP Nomor 10 Tahun 2006 tentang Badan Pertanahan Nasional yang menjelaskan tentang Penanganan masalah, sengketa, dan konflik pertanahan secara hukum dan nonhukum yang artinya kebijakan pemerintah dalam mengupayakan mediasi sebagai alternatif penyelesaian sengketa pertanahan. Dengan pendekatan mediasi yang dilakukan oleh Badan Pertanahan Nasional maka akan memberikan solusi penyelesaian sengketa pertanahan yang musyawarah dan mufakat. Sehingga kedua belah pihak dapat melakukan kesepakatan dalam penyelesaian sengketa pertanahan.

Penerapan mediasi dalam penyelesaian sengketa pertanahan telah digunakan dalam praktek berdasarkan Peraturan Kepala BPN RI Nomor 3 Tahun 2011 tentang pengelolaan Pengkajian dan Penanganan Kasus Pertanahan. Dalam penggunaan cara mediasi yang telah dilakukan oleh Badan Pertanahan Nasional telah berhasil menyelesaikan suatu sengketa pertanahan yang diajukan oleh kedua belah pihak yang bersengketa. Sehingga, kesepakatan mediasi tersebut diartikan sebagai kesepakatan yang telah dicapai oleh para pihak dengan bantuan mediator.

Dengan dicapainya suatu kesepakatan $^{18}$ tersebut maka pihak BPN

17 Wayan Wiriyawan, I Ketut Artadi, Penyelesaian Sengketa Diluar Pengadilan, (Denpasar, Udayana University Press : 2010), 26.

18 Kesepakatan adalah persesuaian pernyataan kehendak antara satu orang atau lebih dengan pihak lainnya. Pertanyaannya adalah "Kapan momentum terjadinya persesuaian pernyataan kehendak tersebut?" Ada empat teori yang menjawab hal ini, yaitu : a) Teori Ucapan (uitingstheorie) Menurut teori ini, Kesepakatan (toesteming) terjadi pada saat pihak yang menerima 
selaku mediator dapat membuatkan akta perdamaian kepada kedua belah pihak yang bersengketa agar dapat mengetahui kedudukan dari pada akta perdamaian yang telah dibuat oleh kedua belah pihak.

Akta perdamaian telah diatur dalam Pasal 130 ayat 2 HIR yang berbunyi:

"Jika perdamaian yang demikian itu dapat dicapai, maka pada waktu bersidang diperbuat sebuah surat (akta) tentang itu, dalam mana kedua belah pihak dihukum akan menaati perjanjian yang diperbuat itu, surat mana akan berkekuatan dan akan dijalankan sebagai putusan biasa".

Artinya bahwa kekuatan hukum suatu akta perdamaian dapat sangat kuat apabila berbentuk putusan, dimana putusan tersebut didalamnya memuat sebuah akta perdamaian, dan akta perdamaian yang telah dibentuk oleh kedua belah pihak melalui suatu kesepakatan yang berisikan perjanjian dibuat dihadapan mediator. Sehingga kekuatan hukum akta perdamaian ini dapat disamakan dengan kekuatan hukum putusan pengadilan yang tercantum di dalam Pasal 1858 ayat (1) KUHPerdata dan juga Pasal 130 ayat (2) HIR dimana

penawaran menyatakan bahwa ia menerima penawaran. Jadi, dilihat dari pihak yang menerima, yaitu pada saat menjatuhkan pulpen untuk menyatakan menerima, kesepakatan sudah terjadi. Kelemahan teori ini adalah sangat teoritis karena menganggap terjadinya kesepakatan secara otomatis. b) Teori Pengiriman (verzendtheorie) Menurut teori ini, kesepakatan terjadi apabila pihak yang menerima penawaran mengirimkan telegram. Kritik terhadap teori ini, bagaimana hal itu bisa diketahui? Bisa saja, walaupun sudah dikirim, tidak diketahui oleh pihak yang menawarkan teori ini juga sangat teoritis, menganggap terjadinya kesepakatan secara otomatis. c) Teori Pengetahuan (venemingstheorie) Teori pengetahuan berpendapat bahwa kesepakatan terjadi apabila pihak yang menawarkan itu mengetahui adanya acceptatie (penerimaan), tetapi penerimaan itu belum diterimanya (tidak diketahui secara langsung). d) Teori penerimaan (ontvangstheorie) Menurut teori ini, toesteming terjadi pada saat pihak yang menawarkan menerima langsung jawaban dari pihak lawan. Lihat R. Joni Bambang, Hukum Ketenagakerjaan, (Bandung: Pustaka Setia, 2013), 87. kedua pasal tersebut memberikan kepastian hukum bahwa akta perdamaian serupa dengan putusan hakim (Pengadilan) yang mengikat dan memiliki kekuatan hukum tetap (res judicata). ${ }^{19}$

a. Gugatan (Litigasi) ${ }^{20}$

Hukum tanah nasional konsepsinya di dasarkan pada hukum adat dan pelaksanaannya mengingat bahwa hukum agraria sekarang ini memakai sistem dan asas-asas hukum adat maka jual beli hak atas tanah sekarang harus pula diartikan sebagai perbuatan hukum yang berupa penyerahan hak milik atau penyerahan tanah untuk selama-lamanya oleh penjual kepada pembeli yang pada saat itu juga menyerahkanharganya kepada penjual. ${ }^{21}$

Masyarakat yang masih menggunakan aturan Hukum Adat yang berlaku. Hal ini bisa dilihat dari cara hidup masyarakatnya yang masih melakukan praktek jual beli hak atas tanah dibawah tangan. Syarat sahnya jual beli hak atas tanah menurut hukum adat adalah terpenuhinya tiga unsur yaitu tunai, riil dan terang. Yang dimaksud dengan tunai adalah penyerahan hak oleh penjual dilakukan bersamaan dengan pembayaran oleh pembeli dan seketika itu juga hak sudah beralih. Harga yang dibayarkan itu tidak harus lunas, selisih harga dianggap sebagai hutang pembeli kepada penjual yang termasuk dalam lingkup hukum hutang piutang bukan hukum pertanahan.

${ }^{19}$ M. Yahya Harapah, Hukum Acara Perdata, (Jakarta: Sinar Grafika, 2005), 279.

${ }^{20}$ Gugatan adalah tuntutan hak yaitu tindakan yang bertujuan memberikan perlindungan yang diberikan oleh pengadilan untuk mencegah perbuatan main hakim sendiri (eigenrichting). Menurut Penulis bahwa gugatan adalah suatu permohonan atau tuntutan hak yang disampaikan kepada Pengadilan yang berwenang terhadap pihak lain agar diperiksa sesuai dengan prinsip keadilan terhadap gugatan tersebut. Ketika sebuah gugatan sampai di depan sidang pengadilan, maka disitu selalu ada pihak penggugat, tergugat dan perkara yang disengketakan. Lihat Sudikno Mertokusumo, Hukum Acara Perdata Indonesia, (Yogyakarta: Liberty, 2002), 52.

21 Boedi Harsono. 2000. Hukum Agraria Indonesia, (Jakarta: Djambatan, 2000), 23. 
Sifat riil berarti bahwa kehendak yang telah diucapkan oleh penjual dan pembeli harus diikuti dengan perbuatan nyata, misalnya dengan diterimanya uang pembayaran oleh penjual dan dibuatnya perjanjian dihadapan kepala desa. Perbuatan hukum jual beli secara terang maksudnya adalah jual beli dilakukan di hadapan kepala desa untuk memastikan bahwa perbuatan itu tidak melanggar ketentuan hukum yang berlaku. Adapun faktor penyebab sering dilakukannya pembelian tanah yang belum atau tidak sekaligus dilaksanakan dihadapan PPAT antara lain: ${ }^{22}$

1) masyarakat kurang paham atau bahkan ketidaktahuan dari si pelaku transaksi baik penjual maupun pembeli tanah mengenai ketentuan hukum yang berlaku;

2) Mula pertama atas dasar hanya karena saling percaya antara penjual dan pembeli dan ketidaktahuan atas hakhak dan kewajiban selaku penjual dan pembeli tanah;

3) Tanah yang menjadi obyek jual beli belum belum dikonversi;

4) Belum mempunyai biaya untuk peralihan haknya atau bahkan juga belum mempunyai dana untuk membayar Pajak Penghasilan (PPh) maupun Bea Perolehan Tanah dan Bangunan (BPHTB);

5) Jenis tanahnya masih merupakan tanah pertanian (sawah/tegal), sedangkan yang dibeli hanya sebagian,sehingga harus dimohon perubahan status tanah tersebut lebih dahulu menjadi tanah perumahan/pekarangan;

6) Jenis tanahnya masih tanah pertanian sedangkan pembeli bertempat tinggal diluar wilayah kecamatan letak tanah yang menjadi obyek jual beli atau bahkan diluar kabupaten atau propinsi, sehingga masih menunggu proses perpindahan penduduk bagi pembeli agar tidak melanggar

\footnotetext{
${ }^{22}$ Prancisca Romana et al., op.cit.
}

ketentuan mengenai absente,atau dalam hal demikian ditempuh jalan dimohon/diproses permohonan perubahan jenis tanah menjadi tanah perumahan lebih dahulu.

7) Guna memudahkan proses peralihan haknya dikarenakan pemilik tanah sudah meninggal dunia, sedangkan ahli warisnya berjumlah cukup banyak. Sebagian besar dari mereka sudah berusia lanjut dan bertempat tinggal jauh dari lokasi tanah yang dijual.

Untuk memulai dan menyelesaikan persengketaan perkara perdata yang terjadi diantara anggota masyarakat, salah satu pihak yang bersengketa harus mengajukan permintaan pemeriksaan kepada pengadilan. Para pihak yang dilanggar haknya dalam perkara perdata disebut penggugat yang mengajukan gugatan kepada pengadilan dan ditujukan kepada pihak yang melanggar (Tergugat) dengan mengemukakan duduk perkara (posita) dan disertai dengan apa yang menjadi tuntutan penggugat (petitum). ${ }^{23}$

Tiap-tiap orang proses perdata dimulai dengan diajukannya surat gugatan secara tertulis bisa juga dengan lisan yang kemudian ditulis kembali atas pemintaan Ketua Pengadilan Agama kepada paniteranya. Gugatan secara lisan ialah bilamana orang yang hendak menggugat itu tidak pandai menulis yang ditujukan kepada Ketua Pengadilan Agama dalam daerah hukum orang yang hendak digugat itu bertempat tinggal. ${ }^{24}$

Selanjutnya untuk lebih jelasnya mengenai bentuk gugatan perdata yang dibenarkan undang-undang dalam praktik, dapat dijelaskan sebagai berikut :

\section{1) Bentuk Lisan}

$\begin{array}{llll}\text { Pasal } & 120 & \text { HIR/144 R.Bg }\end{array}$ menyatakan bilamana penggugat tidak dapat menulis, maka gugatan dapat

23 Gatot Supramono, Hukum Pembuktian di Peradilan Agama, (Bandung: Alumni, 1993), 14.

${ }^{24}$ Elise T. Sulistini dan Rudy T Erwin, Petunjuk Praktis Menyelesaikan Perkara-Perkara Perdata, (Jakarta: Bina Aksara, 1987), Cet. II, 17. 
diajaukan secara lisan kepada ketua Pengadilan. Ketua Pengadilan tersebut membuat catatan atau menyuruh mebuat catatan tentang gugatan itu. Dan dalam R.Bg menyatakan bahwa gugatan secara lisan, tidak boleh dilakukan oleh orang yang dikuasakan. ${ }^{25}$ Tujuan memberikan kelonggaran mengajukan gugatan secara lisan, untuk membuka kesempatan kepada para rakyat pencari keadilan yang buta aksara membela dan mempertahankan hak-haknya. Menghadapi kasus yang seperti ini fungsi pengadilan untuk memberikan bantuan sebagaimana yang digariskan dalam pasal 119 HIR atau Pasal 143 ayat 1 R.Bg jo. Pasal 58 ayat 2 UU No. 7 Tahun 1989. Dalam memberi bantuan memformulasikan gugat lisan yang disampaikan, ketua pengadilan tidak boleh menyimpang dari maksud dan tujuan yang dikehendaki penggugat. ${ }^{26}$

Untuk menghindari hal di atas, maka hakim atau pegawai pengadilan yang ditunjuk oleh ketua pengadilan dalam merumuskan gugatan lisan dalam bentuk surat gugatan dapat melaksanakan langkah-langkah berikut, yaitu: mencatat segala kejadian dan peristiwa sekitar tuntutan yang diminta oleh penggugat, kemudian merumuskan dalam surat gugatan yang mudah dipahami; gugatan yang telah dirumuskan dalam sebuah surat gugatan itu dibacakan kepada penggugat, apakah segala hal yang menjadi sengketa dan tuntutan telah sesuai dengan kehendak penggugat; apabila sudah sesuai dengan kehendak penggugat, maka surat gugatan itu ditandatangani oleh hakim atau pegawai pengadilan yang merumuskan gugatan tersebut. ${ }^{27}$

\section{2) Bentuk Tertulis}

25 M. Fauzan, Pokok-Pokok Hukum Acara Perdata Peradailan Agama dan Mahkamah Syari'ah di Indonesia, (Jakarta: Kencana, Cet.II, 2005), 13.

${ }^{26}$ Yahya Harahap, Kedudukan Kewenangan Dan Acara Peradilan Agama UU No. 7 Tahun 1989, (Jakarta : Sinar Grafika, 2001), Edisi II, 188.

27 Abdul Manan, Penerapan Hukum Acara Perdata di Lingkungan Peradilan Agama, (Jakarta: Yayasan Al hikmah, 2000), 24.
Bentuk Tertulis Gugatan yang paling diutamakan adalah gugatan dalam bentuk tertulis. Hal ini ditegaskan dalam Pasal 118 ayat (1) HIR yang menyatakan bahwa: ${ }^{28}$

"Gugatan perdata, yang pada tingkat pertama masuk kekuasaan pengadilan negeri, harus dimasukkan dengan surat permintaan yang ditandatangani oleh penggugat atau oleh wakilnya menurut Pasal 123, kepada ketua pengadilan negeri di daerah hukum siapa tergugat bertempat diam atau jika tidak diketahui tempat diamnya, tempat tinggal sebetulnya."

Mengenai gugatan tertulis selain dijelaskan dalam HIR, juga dijelaskan dalam R.Bg Pasal 142 ayat (1) yang menyatakan bahwa: ${ }^{29}$

"Gugatan-gugatan perdata dalam tingkat pertama yang menjadi wewenang pengadilan negeri dilakukan oleh penggugat atau oleh seseorang kuasanya yang diangkat menurut ketentuanketentuan dalam pasal 147, dengan suatu surat permohonan yang ditandatangani olehnya atau oleh kuasa tersebut dan disampaikan kepada ketua pengadilan negeri yang menguasai wilayah hukum tempat tinggal tegugat, atau jika tempat tinggalnya tidak diketahui di tempat tinggalnya yang sebenarnya."

Menurut kedua Pasal di atas, gugatan perdata harus dimasukkan kepada Pengadilan dengan surat permintaan yang ditandatangani oleh penggugat atau kuasanya.

Pertama, yaitu dengan melakukan pendaftaran gugatan tersebut ke Pengadilan. Menurut Pasal 118 ayat 1 HIR, pendaftaran gugatan itu di ajukan ke 7 Pengadilan Negeri berdasarkan kompetensi relatifnya berdasarkan tempat tinggal tergugat atau domisili hukum yang ditunjuk dalam perjanjian. Gugatan

28 Ropaun Rambe, Hukum Acara Perdata Lengkap, (Jakarta: Sinar Grafika, 2004), Cet. III, 241.

${ }^{29}$ Ibid, 191. 
tersebut hendaknya diajukan secara tertulis, ditandatangani oleh penggugat atau kuasanya, dan ditujukan kepada Ketua Pengadilan Negeri. Pendaftaran gugatan itu dapat dilakukan dikantor kepanitraan Pengadilan Negeri. Setelah gugatan diajukan di kepanitraan,

Kedua, Penggugat wajib membayar biaya perkara. Biaya perkara yang dimaksud adalah panjar biaya perkara, yaitu biaya sementara yang finalnya akan diperhitungkan setelah adanya putusan Pengadilan Negeri.

Ketiga, register perkara adalah pencatatan gugatan ke dalam buku register perkara untuk mendapatkan nomor gugatan agar dapat diproses lebih lanjut. Registrasi perkara dilakukan setelah dilakukanya pembayaran panjar biaya perkara. Bagi gugatan yang telah diajukan pendaftarannya ke Pengadilan Negeri, namun belum dilakukan pembayaran panjar biaya perkara, maka gugatan tersebut belum dapat dicatat di dalam buku register perkara. Kemudian pelimpahan berkas perkara kepada Ketua Pengadilan Negeri, setelah Panitera memberikan nomor perkara berdasarkan nomor urut dalam buku register perakara, perkara tersebut dilimpahkan kepada Ketua Pengadilan Negeri. Pelimpahan tersebut harus dilakukan secepat mungkin agar tidak melanggar prinsip-prinsip penyelesaian perkara secara sederhana, cepat dan biaya ringan, selambatlambatnya 7 hari dari tanggal registrasi.

Keempat, penetapan Majelis Hakim oleh Ketua Pengadilan Negeri, setelah Ketua Pengadilan Negeri memeriksa berkas perkara yang diajukan Panitera, kemudian Ketua Pengadilan Negeri menetapkan Majelis Hakim yang akan memeriksa dan memutus perkara. Penetapan itu harus dilakukan oleh Ketua Pengadilan Negeri selambat-lambatnya 7 hari setelah berkas perkara diterima oleh Ketua Pengadilan Negeri. Majelis Hakim yang akan memeriksa dan memutus perkara tersebut terdiri dari sekurangkurangnya 3 orang hakim, dengan komposisi 1 orang Ketua Majelis Hakim dan 2 lainnya Hakim Anggota.

Kelima, Majelis Hakim tersebut kemudian menetapkan hari sidang. Penetapan itu dituangkan dalam surat penetapan. Penetapan itu dilakukan segera setelah Majelis Hakim menerima berkas perkara. Setelah hari sidang ditetapkan, selanjutnya Majelis Hakim memanggil para pihak (Penggugat dan Tergugat) untuk hadir pada hari sidang yang telah ditentukan.

Adapun dasar dari gugatan Penggugat adalah sebagai berikut:

1) Alasan gugatan Penggugat adalah perbuatan melawan hukum yaitu adanya perbuatan melawan hukum yang dilakukan oleh Tergugat karena melakukan penguasaan tanah oleh bukan pemilik tanpa ada persetujuan atau izin dari Pemilik.

2) Tuntutan Penggugat kepada Tergugat adalah pengosongan objek sengketa dan tuntutan ganti rugi baik materiil maupun immateriil.

3) Gugatan Penggugat adalah jelas dan terang benderang baik mengenai alas gugatnya, positanya, maupun petitumnya, sehingga gugatan Penggugat adalah jelas atau tidak kabur (Obscuur Libel).

4) Penggugat telah memenuhi persyaratan keabsahan jual beli sehingga sah melakukan pengusaan obyek tanah hanya saja transaksi jual beli dilakukan di bawah tangan, sedangkan Tergugat jelas bersalah dan harus membayar ganti kerugian.

5) Hakim sudah sudah sepantasnya menjatuhkan hukuman kepada pihak Tergugat karena jelas melanggar hak dari Penguggat untuk menghuni rumahnya. Kemudian Hakim sudah pantas menjatuhkan hukuman yang tidak kabur dan mempunyai kekuatan hukum tetap, sehingga apabila pihak Tergugat tidak puas terhadap isi putusan yang dijatuhkan hakim, maka Tergugat mempunyai hak untuk melakukan upaya hukum lain yaitu 
Banding maupun Verset terhadap putusan yang telah dilaksanakan.

6) Hakim Ketua Pengadilan Negeri Surakarta sudah pantas menjatuhkan putusan dengan dasar bahwa perbuatan melawan hukum, Pasal 1365 BW “Tiap perbuatan melawan hukum, yang membawa kerugian kepada seseorang yang lain, mewajibkan orang yang karena salahnya menerbitkan kerugian itu, mengganti kerugian tersebut".

\section{KESIMPULAN}

Berdasarkan hasil penelitian dan pembahasan dapat dikemukakan kesimpulan sebagai berikut:

1. Bahwa keabsahan Jual Beli Tanah yang dilakukan dibawah tangan tanpa akta Pejabat Pembuat Akta Tanah (PPAT) tetaplah sah, karena sudah terpenuhinya syarat sahnya jual beli menurut UUPA yaitu syarat materiil yang bersifat tunai, terang dan riil. Selain itu juga jual beli tersebut sudah memenuhi syarat jual beli menurut Pasal 1320 KUHPerdata syarat sahnya perjanjian. Tetapi untuk memperoleh pemindahan hak atas tanah dan balik nama harus memiliki akta yang dibuat oleh PPAT karena pemindahan hak atas tanah melalui jual beli tanah harus dibuktikan dengan akta yang dibuat oleh PPAT;

2. Bahwa upaya hukum penyelesaian sengketa jual beli tanah secara di bawah tangan yang dapat dilakukan oleh pihak pembeli agar jual beli tanah yang dilakukan tanpa akta PPAT dapat mempunyai kekuatan hukum yang pasti dengan cara penyelesaiannya sebagai berikut:

1) Mediasi (Non-Litigasi)

Pendekatan mediasi yang

dilakukan oleh Badan

Pertanahan Nasional

Penyelesaian sengketa dan konflik dilakukan berdasarkan inisiatif dari pengaduan masyarakat dan kementerian, maka akan memberikan solusi penyelesaian sengketa pertanahan yang musyawarah dan mufakat sebagaimana diatur oleh:

a) Peraturan Menteri Agraria dan Tata Ruang/Kepala Badan Pertanahan Nasional Republik Indonesia Nomor 11 Tahun 2016 tentang Penyelesaian Kasus Pertanahan;

b) Keputusan Badan Pertanahan Republik Indonesia Nomor 11 Tahun 2009 tentang kebijakan dan Strategi Kepala BPN Republik Indonesia Menangani dan Menyelesaiakan Sengketa, Konflik dan Perkara Pertanahan Tahun 2009;

c) Keputusan Kepala Badan Pertanahan Nasional Nomor 34 Tahun 2007 tentang Petunjuk Teknis Penanganan dan penyelesaian Masalah Pertanahan;

d) Petunjuk Teknis Badan Pertanahan Nasional Republik Indonesia Nomor: 05/JUKNIS/D.V/2007;

e) Keputusan Kepala BPN Republik Indonesia Nomor 34 Tahun 2007 tentang Mekanisme Pelaksanaan.

2) Gugatan (Litigasi)

Untuk memulai dan menyelesaikan persengketaan perkara perdata yang terjadi diantara anggota masyarakat, salah satu pihak yang bersengketa harus mengajukan permintaan pemeriksaan (megajukan gugatan) kepada pengadilan. Para pihak yang dilanggar haknya dalam perkara perdata disebut 
penggugat yang mengajukan gugatan kepada pengadilan dan ditujukan kepada pihak yang melanggar (Tergugat) dengan mengemukakan duduk perkara (posita) dan disertai dengan apa yang menjadi tuntutan penggugat (petitum).

\section{DAFTAR PUSTAKA}

\section{Buku:}

Ali Achmad, 2009, Menguak Teori Hukum dan Teori Peradilan, Jakarta: Kencana Prenadamedia Group.

Bambang R. Joni, 2013, Hukum Ketenagakerjaan, Bandung: Pustaka Setia.

Boedi Harsono, 2000, Hukum Agraria Indonesia, Jakarta: Djambatan.

Elise T. Sulistini dan Rudy T Erwin, 1987, Petunjuk Praktis Menyelesaikan Perkara-Perkara Perdata, Jakarta: Bina Aksara, Cet. II.

Fauzan M, 2005, Pokok-Pokok Hukum Acara Perdata Peradailan Agama dan Mahkamah Syari'ah di Indonesia, Jakarta: Kencana, Cet.II.

Gatot Supramono, 1993, Hukum Pembuktian di Peradilan Agama, Bandung: Alumni.

Harahap M. Yahya, 2005, Hukum Acara Perdata, Jakarta: Sinar Grafika.

Harahap Yahya, 2001, Kedudukan Kewenangan Dan Acara Peradilan Agama UU No. 7 Tahun 1989, Jakarta : Sinar Grafika, 2001, Edisi II.

Manan Abdul, 2000, Penerapan Hukum Acara Perdata di Lingkungan Peradilan Agama, Jakarta: Yayasan Al hikmah.
Manan Abdul, 2005, Penerapan Hukum Acara Perdata di Lingkungan Peradilan Agama, Jakarta: Kencana Prenada Media.

Mertokusumo Sudikno, 2002, Hukum Acara Perdata Indonesia, Yogyakarta: Liberty.

Mustafa Bachsan, 2001, Sistem Hukum Administrasi Negara Indonesia, Bandung: Cipta Aditya Bakti.

Rambe Ropaun, 2004, Hukum Acara Perdata Lengkap, Jakarta: Sinar Grafika, Cet. III.

Sembiring Jimmy Joses, 2011, Cara Menyelesaikan Sengketa di Luar Pengadilan, Jakarta: Visimedia.

Sutedi Adrian, 2006, Peralihan Hak Atas Tanah Dan Pendaftaranya, Jakarta: Sinar Grafika.

Takdir Rahmadi, 2012, Mediasi Penyelesaian Sengketa Melalui Pendekatan Mufakat, Jakarta : PT Raja Grafindo Persada.

Wayan Wiriyawan, I Ketut Artadi, 2010, Penyelesaian Sengketa Diluar Pengadilan, Denpasar , Udayana University Press.

\section{Jurnal:}

Novita, Cici Fajar. "Tinjauan Hukum Terhadap Jual Beli Tanah Tanpa Akta Ppat (Wilayah Kecamatan Tinombo)." Jurnal Ilmu Hukum Legal Opinion 2, no. 5 (2014).

http://jurnal.untad.ac.id/jurnal/index.php/LO/ar ticle/view/5773/4536.

Romana, Prancisca, Dwi Hastuti, Toto Susmono Hadi, and Hartiwingsih. "Keabsahan Jual Beli Hak Atas Tanah Dibawah Tangan Di Desa Patihan Kecamatan Sidoharjo Kabupaten Sragen (Tinjauan Beberapa Kasus Terkait Di Pengadilan Negeri Di Surakarta )." Jurnal Repertorium II, no. 2 (2015): 117-25. 
Saleh, K. Wantjik. Hak Anda Atas Tanah. Jakarta: Ghalia Indonesia, 1982.

Wahid, Abdul, Elya Kusuma Dewi, and Sarip Sarip. "Kekuatan Alat Bukti Akta Otentik Terhadap Akta Pejabat Pembuat Akta Tanah ( PPAT ) Berdasarkan Peraturan Pemerintah Nomor 24 Tahun 2016 Juncto Pasal 1868 KUHPerdata." Mahkamah: Jurnal Kajian Hukum Islam 4, no. 2 (2019): 205-19. https://doi.org/10.24235/mahkamah.v4i2 .5372 .

Marindi Cintyana, Keabsahan Jual Beli Di Bawah Tangan Atas Tanah Bersetipikat (Studi Kasus Perkara No 305/ Pdt G/ 2009/ PN Smg), Diponegoro Law Review, Volume 1, No. 4, Tahun 2012, 1-7. $\quad$ http://ejournals1.undip.ac.id/index.php/dlr.

Mardalena Hanifah, "Kajian Yuridis Mediasi sebagai Alternatif Penyelesaian Sengketa Perdata di Pengadilan", Jurnal HAPER, 2:1( Januari-Juni 2016), 3.

\section{Peraturan Perundang-undangan:}

Undang-Undang Nomor 5 Tahun 1960 Tentang Peraturan Dasar Pokok-Pokok Agraria.

Undang-Undang Nomor 30 Tahun 1999 Tentang Arbitrase Dan Alternatif Penyelesaian Sengketa.

Undang-Undang Nomor 24 Tahun 1997 Tentang Pendaftaran tanah.

Kitab Undang-Undang Hukum Perdata (KUHPerdata).

Peraturan Pemerintah Nomor 10 Tahun 2006 tentang Badan Pertanahan Nasional.

Peraturan Menteri Agraria dan Tata Ruang/Kepala Badan Pertanahan Nasional Republik Indonesia Nomor 11
Tahun 2016 tentang Penyelesaian Kasus Pertanahan;

Peraturan Kepala BPN RI Nomor 3 Tahun 2011 Tentang Pengelolaan Pengkajian Dan Penanganan Kasus Pertanahan.

Peraturan Mahkamah Agung Nomor 1 Tahun 2016 Tentang Prosedur Mediasi di Pengadilan.

Keputusan Badan Pertanahan Republik Indonesia Nomor 11 Tahun 2009 tentang kebijakan dan Strategi Kepala BPN Republik Indonesia Menangani dan Menyelesaiakan Sengketa, Konflik dan Perkara Pertanahan Tahun 2009.

Keputusan Kepala Badan Pertanahan Nasional Nomor 34 Tahun 2007 tentang Petunjuk Teknis Penanganan dan penyelesaian Masalah Pertanahan.

Petunjuk Teknis Badan Pertanahan Nasional Republik Indonesia Nomor: 05/JUKNIS/D.V/2007.

Keputusan Kepala BPN Republik Indonesia Nomor 34 Tahun 2007 tentang Mekanisme Pelaksanaan.

\section{Internet :}

https://tafsirq.com/49-al-hujurat/ayat-9.

http://ejournal-s1.undip.ac.id/index.php/dlr 